\title{
The Role Of Land Deed Officials In The Conversion of Agriculture Land Fucntion Related Land Social Function In Sragen Regency
}

\author{
Sri Prihartini ${ }^{1}$, Yuliantoro ${ }^{2}$ and Gunarto ${ }^{3}$
}

Abstract. This study aims to analyze the role, constraints and solutions of Land Deed Officials in the conversion of agricultural land related to social functions on land in Sragen Regency. In case conversion of agricultural land is associated with social functions on land, cannot be avoided, especially if the land is for a highway development project as is the case in Sragen Regency which also involves the role of Land Deed Officials. The role of Land Deed Officials in the conversion of agricultural land to highway development projects carried out within the period of 2014-2015 is the provision of consultation to the community included in the authority of PPAT. Thus, Land Deed Officials can provide assistance in managing the conversion of agricultural land to the community. Meanwhile, in the conversion of agricultural land for highway construction, there is no significant obstacle because the Land Deed Officials manages the transfer of agricultural land functions according to procedures set by the Regulation of the Head of the National Land Agency Number 2 year 2011 concerning Guidelines for Land Technical Considerations in Issuance of Location Permits, Determination Location, and Permission to Change Land Use. Thus, if in handling the conversion of agricultural land is in accordance with the provisions of existing regulations, the Land Deed Officials will be able to overcome the existing obstacles.

Keywords: Role of Land Deed Officials; Conversion of Agricultural Land Function; Land Social Function

\section{Introduction}

Land expansion in human life has meaning and at the same time has a dual function, namely as a social asset and capital asset. As social assets, land is a means of binding social unity among the community for life and life. On the other hand, as capital assets, land is the capital factors in development and has grown as very important economic objects as well as commercial materials and objects of speculation. ${ }^{4}$

The existence of land as an important natural resource for the state of Indonesia is regulated in Law Number 5 year 1960 concerning Basic Agrarian Principles (In Indonesian known as UUPA) Article 1 paragraph (1) which states that "all land in the territory of the Republic of Indonesia is a common land of all Indonesian people". Furthermore, in Article 6 of the BAP (Basic Agrarian Principles), it states that "all rights to land have social functions". The article is further stated as one of the principles of land law which is termed the principle of social functions of land rights. The existence of the principle of the social function of land rights in the land law is a fundamental foundation for the realization of land that benefits the greatest prosperity of the people.

Associated with the existence of the principle of social functions of land rights in the state of law as one of the principles of agrarian law, it has a very important role in realizing the goals of the country. It contains the meaning in the principle of social functions of land

\footnotetext{
${ }^{1}$ Student of Master Program in Notary Law Faculty of Law, Universitas Islam Sultan Agung email prihatini.r26@gmail.com

2 Students of Master of Law, Faculty of Law, Universitas Islam Sultan Agung email syarifudinarif130398@gmail.com

3 Professor of Faculty of Law UNISSULA

${ }^{4}$ Ahmad Rubaie 2007 Hukum Pengadaan Tanah untuk Kepentingan Umum Bayumedia Malang p.1.
} 
rights, the fulfillment of rights to land for the greatest prosperity of the people as stipulated in the constitution of the 1945 Constitution.

However, in its development, the land as an agrarian resource has not been guaranteed and maintained its benefits to fulfill the prosperity of the people. The existence of land has not been able to fulfill the mutual benefit in the concept of social functions of land rights. One of the problems that currently arises is the fulfillment of the common needs of all people in the concept of social function, namely the availability of agricultural land to meet food demand. This condition is experienced in many regions that have the potential as an agricultural region which land is very productive to produce agricultural production. One of the rice producing areas which the land has agricultural potential is in Sragen Regency, Central Java Province.

Sragen Regency is one of the second largest rice barns in Central Java after Grobogan. But now, agricultural production in Sragen, especially rice, has recently declined due to reduced agricultural land due to land conversion. Whether for road, residential or industrial infrastructure. Especially for road infrastructure, 220 hectares of agricultural land in Sragen Regency, Central Java were lost due to the Solo-Kertosono (Soker) highway project.

The increasing need for land intended for development activities both by the government and the private sector has consequences for the government to provide land for these activities, while the available land is limited. This situation forced the government to take over the people's land. The transfer of agricultural land to non-agricultural functions occurs widely in line with development policies that emphasize the growth aspect through the ease of investment facilities, both for local and foreign investors in the provision of land. The conversion of land that was originally used for agriculture into non-agricultural land is a major factor in the lack of agricultural land. ${ }^{5}$

Like the conversion of agricultural land that occurred in Sragen Regency, one of the factors that caused it was the existence of national projects that crossed the area of productive rice fields. The national project is the construction of the Solo - Kertosono (Soker) Highway which passes in 3 Regencies and 1 City, namely Boyolali Regency, Sragen Karanganyar and Solo City. Especially for Sragen, the construction of the highway continues between Semarang Central Java and Kertosono, East Java. The acquisition of land by the government was to carry out development aimed at meeting the public interest. In the existence of land acquisition activities, there has been a release of the right to agricultural land from the holder of the right to agricultural land to the government agency.

Thus, related to the existence and function of the land, there is a legal relationship between humans and land. The relationship includes transitional actions and the release of land rights in order to provide legal certainty for the intended act. Therefore, it is necessary to involve the role of the Land Deed Officials (PPAT). PPAT is any person who carries out his duties and who functions as a public official. As a public official, the PPAT is given the authority to make authentic deeds regarding certain legal actions concerning land rights or Ownership Rights to Flats ${ }^{6}$. Therefore, based on this understanding, PPAT can help the community to manage the conversion of agricultural land to non-agriculture, which in this case is for the construction of highways in Sragen Regency. Although the existence of the project has resulted in a decline in agricultural productivity.

Based on this background, the problem in this study is how the role of Land Deed Officials in the conversion of agricultural land and the obstacles encountered as well as the solution of PPAT in the conversion of agricultural land related to social functions on land in Sragen

\footnotetext{
${ }^{5}$ Widjanarko dkk 2006 Aspek Pertanahan Dalam Pengendalian Alih Fungsi Lahan Pertanian (Sawah) Pusat Penelitian dan pengembangan BPN Jakarta p. 60.

${ }^{6}$ Parlindungan Sianipar 1995 Pedoman Pelaksanaan dan Tata Cara Pejabat Pembuat Akta Tanah Mandar Maju Bandung p. 97.
} 
Regency.

\section{Research Methods}

The type of research used was juridical empirical legal research, because the approach used was a combination of normative juridical and sociological juridical. ${ }^{7}$ Meanwhile, the research specification is descriptive analytical. Furthermore, the location of the research was in Sragen Regency. The data sources used were primary and secondary data while data collection was done through literature study, observation and interviews which are then analyzed using qualitative data.

\section{Research Results And Discussion}

\subsection{The Role of PPAT in the conversion of Agricultural Land Functions Related to the Social Function of Land in Sragen Regency}

Land has an important role because land is a source of prosperity, welfare and life. It gives an understanding that it is a national responsibility to realize the welfare and prosperity of the people as in Article 33 paragraph (3) of the 1945 Constitution, which states that the water and natural resources contained therein are controlled by the state and used for the greatest prosperity of the people. The provisions in Article 33 paragraph (3) are then further elaborated in Article 2 paragraph (1) of Law Number 5 year 1960 concerning Basic Agrarian Principles, better known as the Basic Agrarian Law (UUPA), which states that the earth, water and space including natural wealth contained therein at a higher level controlled by the state as an organization of power of all people.

The right to control the state means that the state has the right to intervene in the sense that every owner or holder of land rights is not free from the right to control the country because the public interest is above the interests of the individual or group interests. However, this does not mean that the interests of individuals or groups can be sacrificed just like that with the pretext of public interest. This is because the land also has social functions as affirmed in Article 6 of the BAL (Basic Agrarian Law) which states that all land rights have social functions. This means that any land rights that exist in a person, cannot be justified, that the land will use (or not be used) solely for his personal interests, especially if it causes harm to the community. The use of land must be adjusted according to the circumstances and the nature of its rights, to be beneficial both for the welfare and happiness that has it as well as beneficial for society and the state. ${ }^{8}$

Regarding the social function of the land, the implementation of infrastructure development requires a very large area of land but these needs are not easy to fulfill. Therefore, the need for community participation in the implementation of development is to be able to cooperate with the government as stipulated in Article 18 of the BAL which states that for the public interest, including the interests of the nation and the state and the common interests of the people, land rights can be revoked by giving appropriate compensation and in the manner regulated in the Law.

At this time, it is very difficult to do development for the public interest on state land. The fact shows that development requires land, on the other hand, the state land available to meet these needs is increasingly limited, because the existing land has been partly controlled by the community with a right. In order to maintain the momentum of development, especially the construction of various facilities for the public interest that require land parcels, the legal efforts of the government to obtain these lands in fulfilling

\footnotetext{
${ }^{7}$ Muslan Abdurrahman 2009 Sosiologi dan Metode Penelitian Hukum UMM Press Malang p. 94.

${ }^{8}$ Boedi Harsono 2000 Himpunan Peraturan-peraturan Hukum Tanah Djambatan Jakarta p. 296.
} 
development are carried out through an approach to freeing rights and revocation of rights. $^{9}$

The taking of residents' land for development purposes or organizing public interests can be done in 3 (three) ways. These three ways include the release or surrender of land rights (land acquisition), revocation of land rights and direct acquisition of hold (buying and selling, exchanging or other voluntarily agreed methods). ${ }^{10}$

Development by the government, especially the construction of highways, absolutely requires land. The land needed, can be in the form of land that is directly controlled by the state (state land) or land that is already owned by a right by a legal subject (land rights). If the land needed for development is in the form of state land, the acquisition of land is not difficult, namely the government can directly apply for the rights to the land for further use for development. However, state land is currently rarely found, therefore the land needed for development is generally land of rights which can be in the form of Ownership Rights, Right to Cultivate, Right to Build, and Right to Use. ${ }^{11}$

The lands needed in the construction of highways in Sragen Regency were mostly paddy fields or agricultural land. It was the livelihood of the land owner or the holder of the land rights, so that there has been a conversion of agricultural land to the construction of the highway. The conversion of agricultural land to non-agricultural functions occurs widely in line with development policies that emphasize the growth aspect through the ease of investment facilities, both for local and foreign investors in the provision of land. ${ }^{12}$

However, highway construction projects carried out by the government are a project that is first planned in the establishment of a development plan for the public interest and in accordance with the General Spatial Planning of the City. The land procurement committee is formed to make and arrange land procurement for the implementation of development by carrying out preliminary activities in the release or delivery of land rights so that directly or indirectly also involve PPAT (Land Deed Officials). ${ }^{13}$

Government Regulation Number 37 Year 1998 Regarding the Position Regulation of the Land Deed Officials states that the so-called Land Deed Officials, commonly abbreviated as PPAT, is a general official who is given the authority to make authentic deeds of certain legal actions concerning land rights or ownership rights on units of flats. In Government Regulation Number 37 year 1998, it also contains temporary PPAT and special PPAT. Temporary PPAT is a government official who is appointed because of his position to carry out PPAT duties and make a deed in the area that is not enough PPAT, in this case the appointed one is the subdistrict head. The special PPAT is an official of the National Land Agency appointed because of his position to carry out PPAT duties by making certain PPAT deeds, specifically in the framework of implementing certain government programs or tasks. ${ }^{14}$

Therefore, this activity also involves the role of PPAT in the process. The Land Deed Officials is one of the instruments that indirectly play a role in the process of releasing land rights or in this case the conversion of agricultural land to highway construction projects in Sragen Regency. The role of PPAT in the conversion of agricultural land to highway development projects carried out in the period of 2014-2015 was the provision of

${ }^{9}$ Chaisi Nasucha 1994 Politik Ekonomi Pertanahan Dan Sumber Perpajakan Atas Tanah Kesaint Blanc Jakarta p. 74.

10 Oloan Sitorus dan Dayat Limbong 2004 Pengadaan Tanah untuk Kepentingan Umum Mitra Kebijakan Tanah Yogyakarta p. 14.

${ }^{11}$ Ibid p. 18.

${ }^{12}$ Widjanarko,dkk op.Citp. 60.

13 Abdurrahman 2004 Pengadaan Tanah Bagi Pelaksanaan Pembangunan Untuk Kepentingan Umum Citra Aditya Bakti Bandung p. 79.

${ }^{14}$ Boedi Harsono op.Citp. 682. 
consultation to the community included in the authority of PPAT. This is based on Article 7 paragraph (1) of Government Regulation Number 37 year 1998 Concerning the Regulation of the Land Deed Officials, which states that Land Deed Officials can concurrently serve as Notary, Consultant, or Legal Counsel so that PPAT can provide assistance in managing the conversion of agricultural land to the public.

Thus, the role of PPAT is in terms of serving the needs of the community relating to land, whether the transfer of land rights, the granting of new rights or other rights relating to land rights. It is undeniable that land is a natural resource which is a primary human need, since there is no human activity not related to the land, including development.

\subsection{The Constraints Faced and the Solution of the Role of Land Deed Officials in the Conversion of Agricultural Land Functions Related to the Social Function of Land in Sragen Regency}

Obstacle is constraint or burden factor ${ }^{15}$. It is undeniable that in carrying out a task or job, there will be an obstacle. A task or job will not be carried out without an obstacle that disrupts the work. Obstacles are conditions that can cause the implementation to be disrupted and not carried out properly. Every human being always has obstacles in daily life, both from human beings themselves or from outside humans. Obstacles tend to be negative, which is slowing down the rate of a thing done by someone. Every time there is an activity, there are often a number of things that hinder the achievement of goals, both obstacles to program implementation and in terms of development.

Infrastructure development activities carried out by the government, especially in the construction of highway projects, are intended to provide maximum benefits for the people. The construction of highway projects, especially in Sragen Regency required a very large amount of land and the pathway affected by the project was mostly land or agricultural land, resulting in the conversion of agricultural land. Therefore, to the land acquisition, the government compensated the parties properly and fairly. Agricultural land acquisition carried out is for the public interest, because the construction of highways in Sragen Regency is a national development project. Public interest is in the interests of the nation, state and society which must be realized by the government and used as much as possible for the prosperity of the people.

Agricultural land acquisition in Sragen Regency for highway construction projects is in the public interest. This is also very relevant to the BAL concerning the social function of the land that if in a state of forced government the government can take or control land in the context of the public interest. Even though in granting land ownership rights have the hereditary rights and the strongest, but if the public interest requires, then the strong property rights can be erased, in the interest of the nation and state. ${ }^{16}$

The most important thing in land acquisition for the public interest is the feasibility of the location to ensure that the targeted location is in accordance with the development that will be made. Therefore, public policy analysis is very important to see how much benefits can be obtained from a policy taken by the government for a project and the possible obstacles that will be faced, especially for parties involved both directly and indirectly in the transfer process function of agricultural land for highway construction projects in Sragen Regency, especially for PPAT.

As for the conversion of agricultural land for highway development, there is no significant obstacle because the PPAT managed the transfer of agricultural land functions according to procedures established by the Regulation of the Head of the National Land Agency No.

${ }^{15}$ Department of Education and Culture 1991 Kamus Besar Bahasa Indonesia Second edition Balai Pustaka Jakarta p. 54.

${ }^{16}$ Abdurrahman op.Citp. 122. 
2 year 2011 concerning Guidelines for Land Technical Considerations in Issuance of Location Permits, Location Determination, and Permission to Change Land Use. Thus, if in handling the conversion of agricultural land in accordance with the provisions of existing regulations, then this will be able to overcome the existing obstacles.

\section{Clossing}

\subsection{Conclusion}

The role of Land Deed Officials in the conversion of agricultural land to highway development projects carried out in the period of 2014-2015 was the provision of consultation to the community included in the authority of PPAT. This is based on Article 7 paragraph (1) of Government Regulation Number 37 year 1998 Concerning the Regulation of the Land Deed Officials, which states that PPAT can concurrently serve as Notary, Consultant, or Legal Counsel so that PPAT can provide assistance in managing the conversion of agricultural land to the public.

As for the conversion of agricultural land for highway development, there is no significant obstacle because the Land Deed Officials managed the transfer of agricultural land functions according to procedures established by the Regulation of the Head of the National Land Agency No. 2 year 2011 concerning Guidelines for Land Technical Considerations in Issuance of Location Permits, Location Determination, and Permission to Change Land Use. Thus, if in handling the conversion of agricultural land in accordance with the provisions of existing regulations, then this will be able to overcome the existing obstacles.

\subsection{Suggestion}

The conversion of agricultural land nowadays is something that cannot be avoided, especially if the land is used for infrastructure development projects, especially highway development projects. Therefore, it is important for local governments and related parties to pay more attention to the conversion of agricultural land, so that it does not harm farmers. If this does not get serious attention from the local government, it will have an impact on the threat of food security, especially Sragen Regency is one of the second largest rice barns in Central Java.

\section{References}

[1] Ahmad Rubaie 2007 Hukum Pengadaan Tanah untuk Kepentingan Umum Bayumedia Malang.

[2] Abdurrahman 2004 Pengadaan Tanah Bagi Pelaksanaan Pembangunan Untuk Kepentingan Umum Citra Aditya Bakti Bandung.

[3] Boedi Harsono 2000 Himpunan Peraturan-peraturan Hukum Tanah Djambatan Jakarta.

[4] Chaisi Nasucha 1994 Politik Ekonomi Pertanahan Dan Sumber Perpajakan Atas Tanah Kesaint Blanc Jakarta.

[5] Departemen Pendidikan dan Kebudayan 1991 Kamus Besar Bahasa Indonesia edisi kedua Balai Pustaka Jakarta.

[6] Muslan Abdurrahman 2009 Sosiologi dan Metode Penelitian Hukum UMM Press Malang.

[7] Oloan Sitorus dan Dayat Limbong 2004 Pengadaan Tanah untuk Kepentingan Umum Mitra Kebijakan Tanah Yogyakarta.

[8] Parlindungan Sianipar 1995 Pedoman Pelaksanaan dan Tata Cara Pejabat Pembuat Akta Tanah Mandar Maju Bandung.

[9] Widjanarko dkk 2006 Aspek Pertanahan Dalam Pengendalian Alih Fungsi Lahan 
Volume 5 Issue 3, September 2018

Pertanian (Sawah) Pusat Penelitian dan pengembangan BPN Jakarta. 